\title{
Biochemical Abnormalities of the Third Component of Complement in Neonates ${ }^{1}$
}

\author{
TERENCE L. ZACH AND MARGARET K. HOSTETTER \\ Divisions of Neonatology [T.L.Z.] and Infectious Diseases [M.K.H.], Department of Pediatrics, University of \\ Minnesota, Minneapolis, Minnesota 55455
}

\begin{abstract}
The third component of complement, C3, is of central importance as an opsonin in the nonimmune host. Although gestational deficiencies in $\mathrm{C} 3$ levels are well recognized in neonates, defects in complement-mediated functions have not in every case correlated with low levels of complement proteins. Because opsonic functions of $\mathrm{C3}$ are mediated through a reactive thiolester bond, we hypothesized that a biochemical dysfunction at this active site could explain the newborn's predisposition to infection, even with relatively normal C3 levels. We therefore examined the biochemical integrity of the $\mathrm{C} 3$ thiolester in an assay independent of all other complement proteins. As measured by ELISA, mean C3 levels from 44 neonates (24-43 wk) were significantly lower in infants $<30$ wk gestational age $(0.79 \pm 0.13 \mathrm{mg} / \mathrm{mL})$ than in full-term newborns $(1.19 \pm 0.27 \mathrm{mg} / \mathrm{ml}, p<0.05)$. Furthermore, biochemical reactivity of the thiolester bond, as measured by incorporation of the radiolabeled nucleophile, methylamine, correlated significantly with gestational age $(r=$ $0.45, p<0.01$ ). Functional $\mathrm{C} 3$ was defined as the product of thiolester reactivity and $\mathrm{C} 3$ level; 9/11 premature and 2/ 17 full-term infants had levels of functional $\mathrm{C} 3$ which were less than $50 \%$ of the adult norm. Structural analysis of neonatal $\mathrm{C} 3$ revealed the two-chain structure in all neonates; four neonates had an additional band at $205 \mathrm{kD}$ which may represent an impairment in posttranslational processing of a precursor molecule. We conclude that defects in thiolester reactivity may constitute a newly identified mechanism for the newborn's susceptibility to infection. (Pediatr Res 26: 116-120, 1989)
\end{abstract}

\section{Abbreviations}

PAS, pooled adult serum

$\mathrm{CH}_{3} \mathrm{NH}_{2}$, methylamine

Sepsis is a leading cause of morbidity and mortality in neonates, with premature infants affected more frequently than fullterm newborns (1). This predisposition to infection is ascribable, at least in part, to age-related defects in host defense $(2,3)$. Primary among humoral defenses are the complement proteins, which serve as opsonins for common neonatal pathogens such as the group B Streptococcus or the K1 capsular serotype of Escherichia coli $(4,5)$.

Received October 17, 1988; accepted April 18, 1989

Correspondence Terence L. Zach, M.D., Box 296 UMHC, University of Minnesota, 420 Delaware St. S.E., Minneapolis, MN 55455.

Supported by NIH Grants AI 07054, 20716 and 24162; by a Basic Research Grant from the National Foundation, March of Dimes; and by a grant-in-aid from the Viking Children's Fund at the University of Minnesota.

${ }^{1}$ Presented in part at the meeting of the Society for Pediatric Research, Washington, D.C., May 3, 1988
The third component of complement, $\mathrm{C} 3$, is the pivotal protein in the opsonization of bacteria by either the classical or the alternative complement pathway. Binding of $\mathrm{C} 3 \mathrm{~b}$ to the bacterial surface constitutes the central mechanism of antibody-independent opsonization and initiates complement-dependent lysis or phagocytosis. The opsonic functions of $\mathrm{C} 3$ are mediated through an internal thiolester bond, which upon activation binds covalently to hydroxyl or amino groups on the microbial surface (6). The presence of the reactive thiolester bond is essential for the opsonic and covalent binding of $\mathrm{C} 3 \mathrm{~b}$ to pathogenic bacteria such as the type III group B Streptococcus (7).

Previous studies have demonstrated quantitative deficiencies in $\mathrm{C} 3$ and other complement proteins in the neonate (8-12). In addition, function of the newborn's complement system is also impaired and may increase the risk of infection (9-13). For example, Cairo et al. (14) have recently shown that a low $\mathrm{CH} 50$, a measure of the hemolytic activity of complement, is the most significant determinant of mortality in septic newborns, regardless of gestational age.

Because of the central role of $\mathrm{C} 3$ in opsonization, we have examined $\mathrm{C} 3$ functional activity per milligram of protein in a manner independent of all other complement proteins. This method permits the ready identification of $\mathrm{C} 3$ dysfunction per se and facilitates the analysis of structural aberrancies as well.

\section{MATERIALS AND METHODS}

Serum. Serum was obtained from cord blood or venous access in 50 neonates, aged $24-43$ wk gestation, within the first $3 \mathrm{~d}$ of life. Review of each infant's hospital chart indicated no clinical or microbiologic evidence of infection. PAS obtained from six nonpregnant adults served as control. Serum was separated by centrifugation and frozen in aliquots at $-70^{\circ} \mathrm{C}$ until testing. The study was approved by the University of Minnesota's Committee on the Use of Human Subjects in Experimentation.

ELISA assay for C3. Purified human C3 was isolated from fresh pooled plasma by the method of Tack et al. (15). Sheep antihuman C3 was a kind gift from Dr. B. F. Tack (La Jolla, CA). Goat anti-human C3 (Atlantic Antibodies, Scarborough, ME) was conjugated to horseradish peroxidase by the periodate method (16). Methods for the ELISA assay, a modification of that developed by Voller et al. (17), have been published previously (18). Briefly, wells of a microtiter plate were coated with a 1:400 dilution of sheep antihuman $\mathrm{C} 3$ in carbonate/bicarbonate buffer ( $\mathrm{pH} 9.6$ ), incubated overnight at $4^{\circ} \mathrm{C}$, and washed three times with $0.05 \%$ Tween 20 in PBS. Serum was serially diluted $1: 5000$ to $1: 20,000$ in $1 \% \mathrm{BSA} / 1 \%$ Tween $20 / \mathrm{PBS}$, added to duplicate wells in a volume of $0.1 \mathrm{~mL}$, and incubated for $1 \mathrm{~h}$ at $37^{\circ} \mathrm{C}$. After three washes, $0.1 \mathrm{~mL}$ of a 1:800 dilution of peroxidase-conjugated goat antihuman $\mathrm{C} 3$ was added to each well, and the incubation was continued for $1 \mathrm{~h}$ at $37^{\circ} \mathrm{C}$. The developing reagent consisted of $0.4 \mathrm{mg} / \mathrm{mL}$ of $o$-phenylenediamine in 0.2 $\mathrm{M} \mathrm{Na}_{2} \mathrm{HPO}_{4}$ (pH 5.0 with $0.1 \mathrm{M}$ citric acid), containing $0.4 \mu \mathrm{L}$ 
$35 \% \mathrm{H}_{2} \mathrm{O}_{2} / \mathrm{mL}$. Color was developed for approximately $25 \mathrm{~min}$. Absorbance was measured at $405 \mathrm{~nm}$ in a Titertek Multiskan ELISA Reader (Flow Laboratories, McLean, VA). The standard curve was calibrated with known concentrations of purified human C3. As additional verification, concentrations of $\mathrm{C} 3$ in PAS and five neonatal serum samples were measured by radial immunodiffusion in the clinical laboratories of the University of Minnesota Hospital (19). As shown in Table 1, there was no significant difference between mean $\mathrm{C} 3$ levels in neonates as determined by ELISA (1.20 \pm 0.38$)$ and RID $(1.18 \pm 0.30, p=$ 0.67 ).

Biochemical assay for reactivity of $\mathrm{C} 3$ thiolester bond. Nucleophilic amines, such as $\mathrm{CH}_{3} \mathrm{NH}_{2}$, are inherently reactive with thiolester bonds; binding of the nucleophile is stoichiometric, with $1 \mathrm{~mol}$ of the nucleophile covalently bound for each mol of thiolester disrupted (20). Titration of thiolester reactivity was performed by a modification of the procedure of Tack et al. (20) and Hostetter et al. (21). Briefly, $0.45 \mathrm{~mL}$ of serum from 34 neonates was incubated with $0.01 \mathrm{~mL}$ of $1 \mathrm{M} \mathrm{CH}_{3} \mathrm{NH}_{2}$ (Sigma Chemical Co., St. Louis, MO) in 0.1 M TRIS/0.01 M EDTA/ pH 8.0; to this was added $0.01 \mathrm{~mL}$ of ${ }^{14} \mathrm{CH}_{3} \mathrm{NH}_{2}$ (Amersham, Arlington Heights, IL) which had been diluted with unlabeled $\mathrm{CH}_{3} \mathrm{NH}_{2}$ to a specific activity of $2.6 \mathrm{mCi} / \mathrm{mmol}$. A 20 -fold molar excess of $0.44 \mathrm{M}$ iodoacetamide (Sigma) in TRIS/EDTA, pH 8.0 , was added to prevent disulfide bond formation. The final volume of the reaction mixture was $0.522 \mathrm{~mL}$. For each day's experiments, $0.45 \mathrm{~mL}$ of PAS, identically treated, served as a control. After 2-h incubation in a water bath at $37^{\circ} \mathrm{C}, \mathrm{C} 3$ was then separated from other serum proteins by affinity chromatography on cyanogen-bromide activated Sepharose-4B (Pharmacia, Piscataway, NJ) which had been coupled to affinity purified goat antihuman C3 (Atlantic Antibodies), according to manufacturer's instructions. Bound $\mathrm{C} 3$ was eluted with $0.02 \mathrm{M} \mathrm{HCl}$, and the concentration of $\mathrm{C} 3$ in each fraction was determined spectrophotometrically at $280 \mathrm{~nm}$. Eluates containing C3 were then pooled and exhaustively dialyzed against $0.1 \%$ SDS in PBS to remove noncovalently bound $\mathrm{CH}_{3} \mathrm{NH}_{2}$. Incorporation of ${ }^{14} \mathrm{CH}_{3} \mathrm{NH}_{2}$ was quantitated with a Beckman LS scintillation counter (Beckman Industries, Fullerton, CA). Reactivity of the $\mathrm{C} 3$ thiolester bond was expressed as mol of ${ }^{14} \mathrm{CH}_{3} \mathrm{NH}_{2}$ incorporated per mol $\mathrm{C} 3$ eluted and was thus independent of the serum level of $\mathrm{C} 3$. Comparative analysis of the $\mathrm{C} 3$ thiolester reactivity of serum obtained from cord blood and venous sampling from four premature neonates showed no differences attributable to source of the serum $(88 \pm 1.9$ versus $92 \pm 16.9 \%, p=0.69)$.

$C 3$ hemolytic assay. Neonatal C3 dysfunction as measured by C3 level and thiolester bond reactivity was confirmed in six premature neonates by a C3 hemolytic assay (Cordis Laboratories, Miami, FL). In brief, serial serum dilutions were incubated in the presence of preformed EAC14 and excess C2 and C5-9. Hemolysis was measured spectrophotometrically at $415 \mathrm{~nm}$, and the $\mathrm{C} 3$ hemolytic titer was determined.

Structural analysis of C3. C3 purified from serum by affinity chromatography was analyzed by SDS-PAGE in a $6 \%$ polyacrylamide gel under reducing conditions according to the procedure of Laemmli (22) and stained with a commercial silver stain (BioRad, Richmond, CA). In other experiments, SDS-PAGE gels

Table 1. C3 concentration by ELISA and radial immunodiffusion (RID)

\begin{tabular}{ccc}
\hline Subject & $\begin{array}{c}\text { ELISA } \\
(\mathrm{mg} / \\
\mathrm{mL})\end{array}$ & $\begin{array}{c}\text { RID } \\
(\mathrm{mg} / \mathrm{mL})\end{array}$ \\
\hline Neonate 1 & 0.86 & 0.92 \\
Neonate 2 & 0.83 & 0.75 \\
Neonate 3 & 1.57 & 1.34 \\
Neonate 4 & 1.13 & 1.08 \\
Neonate 5 & 1.63 & 1.50 \\
PAS & 1.68 & 1.81 \\
\hline
\end{tabular}

were transferred to nitrocellulose paper (Sigma) in a 40 -min transfer, according to the conditions of Towbin et al. (23). The transferred proteins were visualized by immunodetection using a biotin-avidin-peroxidase system as previously described (6). Nonspecific binding sites were blocked by incubation with $1 \%$ BSA. The nitrocellulose was then incubated sequentially at $23^{\circ} \mathrm{C}$ with 1:250 (v/v) goat antihuman $\mathrm{C} 3$ for $1 \mathrm{~h}, 1: 500(\mathrm{v} / \mathrm{v})$ biotin conjugated rabbit antigoat IgG (Cappel Laboratories, Malvern, PA) for $40 \mathrm{~min}$, and 1:500 (v/v) peroxidase-conjugated avidin (Cappel) for $30 \mathrm{~min}$. Three 5-min washes with PBS/0.05\% Tween 20 were performed after each incubation, and the blot was then

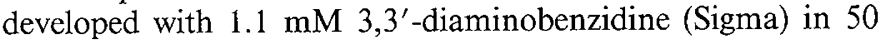
$\mathrm{mM}$ TRIS $/ 0.3 \% \mathrm{H}_{2} \mathrm{O}_{2}$ (pH 7.4).

Statistical analysis. The two-tailed Student's $t$ test, ANOVA, and linear regression analysis for determination of the coefficient of correlation were used for statistical analysis. Results are expressed as mean $\pm \mathrm{SD}$ and $p<0.05$ was considered statistically significant.

\section{RESULTS}

Concentrations of $\mathrm{C} 3$ in neonatal and adult sera. Levels of $\mathrm{C} 3$ in serum from 44 neonates ranged from 0.49 to $1.74 \mathrm{mg} / \mathrm{mL}$. Concentration of C3 in PAS was $1.68 \mathrm{mg} / \mathrm{mL}$. As shown in Figure 1 , mean C3 levels were significantly lower in infants $<30$ wk gestation $(0.79 \pm 0.13 \mathrm{mg} / \mathrm{mL})$ than in full-term newborns $(1.19 \pm 0.27 \mathrm{mg} / \mathrm{mL}, p<0.05)$. C3 concentrations at $30-37 \mathrm{wk}$ gestation $(1.02 \pm 0.37 \mathrm{mg} / \mathrm{mL})$ were not significantly different from either group.

Reactivity of $\mathrm{C} 3$ thiolester. Reactivity of the $\mathrm{C} 3$ thiolester was quantitated by incorporation of the radiolabeled nucleophile ${ }^{14} \mathrm{CH}_{3} \mathrm{NH}_{2} . \mathrm{CH}_{3} \mathrm{NH}_{2}$ incorporation was measured daily in PAS and ranged from $0.88-0.96 \mathrm{~mol}$ of methylamine/mol of $\mathrm{C} 3$.

Incorporation of $\mathrm{CH}_{3} \mathrm{NH}_{2}$ in neonatal $\mathrm{C} 3$ is shown in Figure 2. Thiolester reactivity correlated significantly with gestational age $(r=0.45, p<0.01)$. All of the premature neonates exhibited reduced thiolester reactivity when compared to PAS (mean $=$

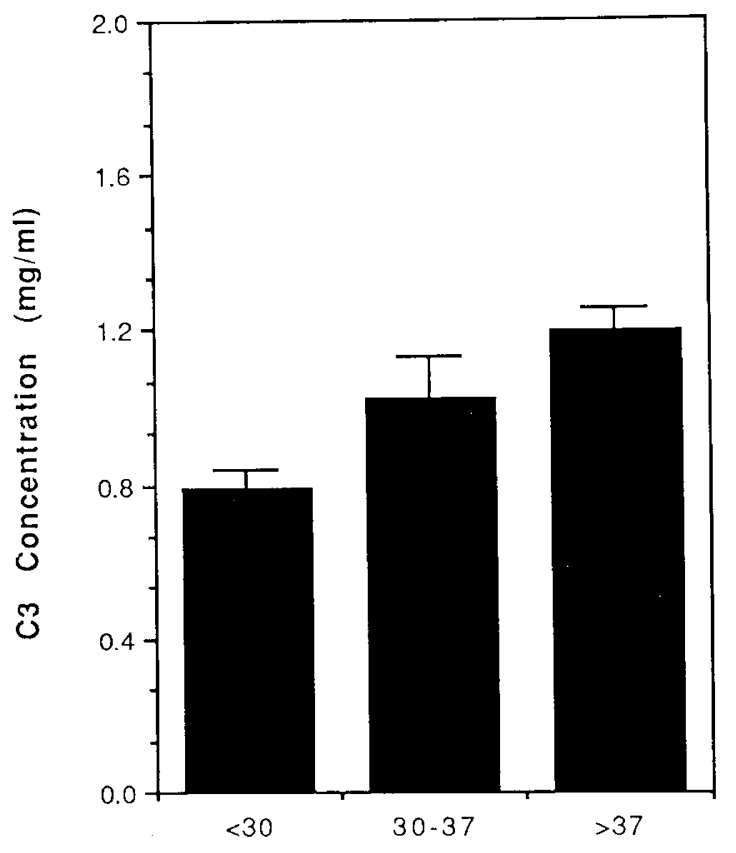

Gestational Age (weeks)

Fig. 1. Mean C3 concentration by ELISA assay in neonates $<30 \mathrm{wk}$ $(n=8)$ was significantly lower than neonates $>37 \mathrm{wk}$ gestation $(n=23$, $p<0.05)$. Neonates $30-37 \mathrm{wk}$ gestation $(n=13)$ were not significantly different from either group. C3 concentration in PAS was $1.68 \mathrm{mg} / \mathrm{mL}$. Values are expressed as mean $\pm \mathrm{SE}$. 


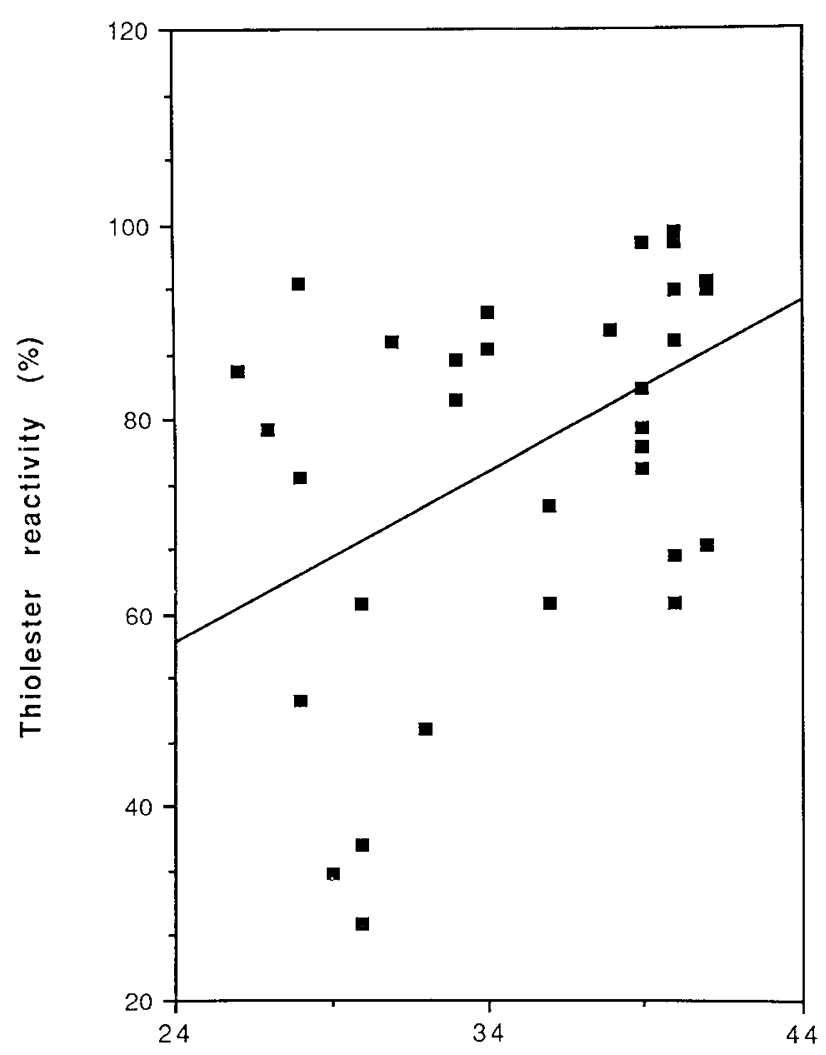

Gestational age (weeks)

Fig. 2. Reactivity of the $\mathrm{C} 3$ thiolester bond in neonates quantified by incorporation of ${ }^{14} \mathrm{CH}_{3} \mathrm{NH}_{2}$. Reactivity of the $\mathrm{C} 3$ thiolester correlates with gestational age $(r=0.45, n=34, p<0.01)$.

$69 \% \pm 22 \%$ ). In full-term newborns, methylamine incorporation ranged from $61-99 \%$ (mean $=85 \% \pm 12 \%$ ).

Functional C3. We defined functional C3 as the product of $\mathrm{C} 3$ concentration and thiolester reactivity. Therefore, for a given concentration of $\mathrm{C} 3$, this value represents the amount that is functionally active. Functional $\mathrm{C} 3$ also correlated well with increasing gestational age $(r=0.63, p<0.001)$ (Fig. 3). Moreover, nine of 11 premature infants and two of 17 term newborns had concentrations of functional C3 which were less than $50 \%$ of the adult norm. A C3 hemolytic assay provided verification of neonatal $\mathrm{C} 3$ dysfunction in six premature neonates. The $\mathrm{C} 3$ hemolytic titers expressed as the neonatal/adult ratio did not differ from the neonatal/adult ratio of calculated functional C3 (respectively, mean $\pm \mathrm{SE}=0.67 \pm 0.22$ versus $0.62 \pm 0.06, p=$ 0.78).

Structural analysis of neonatal C3. The structure of neonatal $\mathrm{C} 3$ isolated from 31 newborns was examined by $6 \%$ SDS-PAGE under reducing conditions. All patients demonstrated the twochain structure of mature C3 with an $\alpha$-chain at $115 \mathrm{kD}$ and a $\beta$-chain at $75 \mathrm{kD}$. Four of the premature infants exhibited a single band at $205 \mathrm{kD}$ which corresponds to the reported structure of pro-C3 (24). By densitometric scanning, all bands other than the $\alpha$-chain and $\beta$-chain constituted $<10 \%$ of the total $\mathrm{C} 3$ (Fig. 4). Bands at $115 \mathrm{kD}(\alpha$-chain) and $75 \mathrm{kD}$ ( $\beta$-chain) were shown to be of $\mathrm{C} 3$ origin by Western blotting and immunodetection with goat antihuman C3 (Fig. 5).

\section{DISCUSSION}

The propensity of the newborn to life-threatening infection is without parallel in later life (1). A variety of deficiencies in host

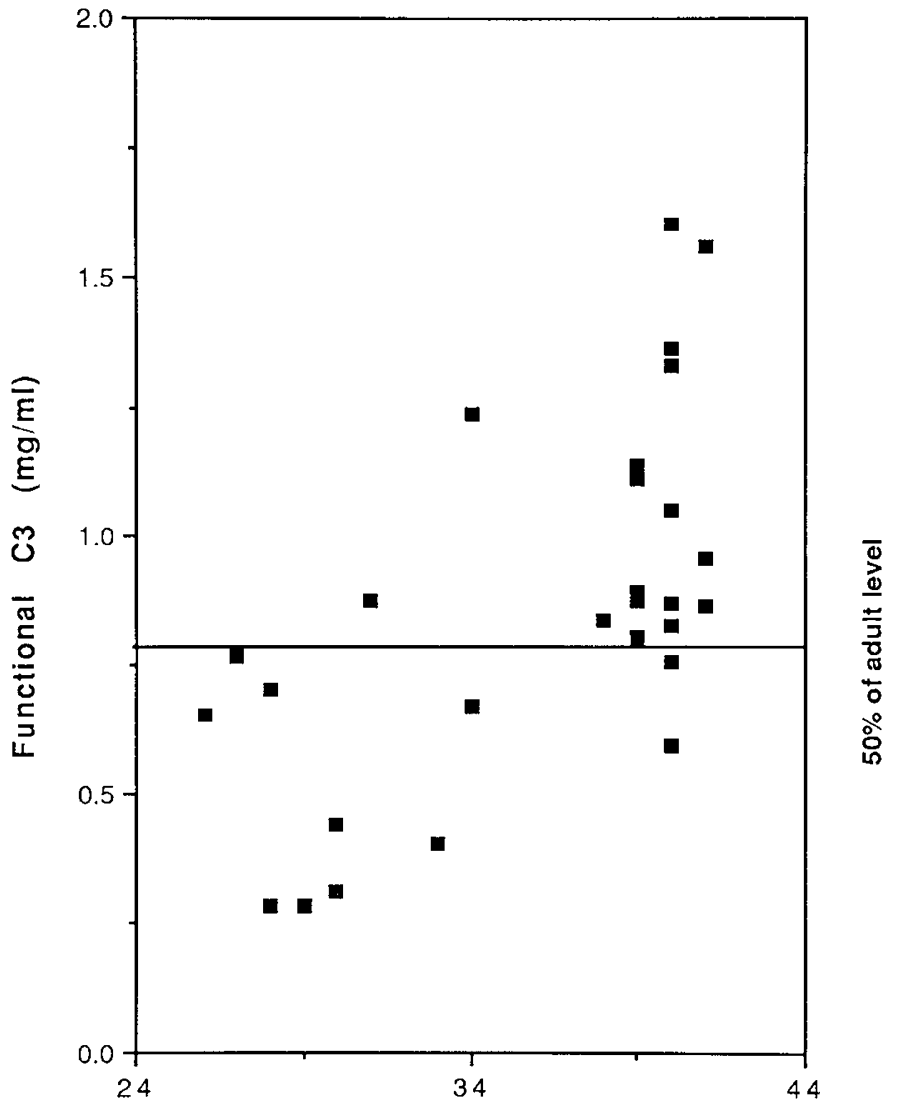

Gestational age (weeks)

Fig. 3. Correlation of functional $\mathrm{C} 3$ with gestational age $(r=0.63, n$ $=28, p<0.001)$. The horizontal line indicates $50 \%$ of the adult norm.

defenses has been described in the neonate, with the premature infant affected more severely than the term neonate $(2,3)$. In the absence of transplacentally acquired antibodies, the neonate must rely on the complement system for opsonization of invading bacterial pathogens. The importance of an intact complement system in septic neonates has been recently emphasized; in the report by Cairo et al. (14), impaired complement function, as measured by an abnormally low $\mathrm{CH} 50$, was the single most important predictor of mortality in infected newborns.

In the complement cascade, C3 sits at the junction of the classical and the alternative pathways of activation. A two-chain protein with an $\alpha$-chain of $115 \mathrm{kD}$ and a $\beta$-chain of $75 \mathrm{kD}, \mathrm{C} 3$ possesses an internal thiolester bond which links a cysteinyl and a glutamyl residue within the C3d subdomain of the $\alpha$-chain (15, 25). Activation of either the classical or the alternative pathway results in the enzymatic cleavage of the $\mathrm{C} 3 \mathrm{a}$ fragment from the amino terminus of the $\alpha$-chain and the formation of $\mathrm{C} 3 \mathrm{~b}$. Concomitant with the formation of $\mathrm{C} 3 \mathrm{~b}$ there is a disruption of the internal thiolester bond with exposure of the reactive glutamyl residue. This residue is the site of covalent attachment of $\mathrm{C} 3 \mathrm{~b}$ to amino or hydroxyl groups on nearby acceptor surfaces (26). The covalent linkage between the reactive glutamyl residue and carbohydrate or amino groups on the bacterial surface is the central mechanism of C3b-mediated opsonization (6).

Using radial immunodiffusion assays, investigators have previously shown that serum concentrations of $\mathrm{C} 3$ are reduced in full-term and premature neonates in comparison to adults. Some have found lower levels in the premature infant in comparison to the term newborn $(8,10-12)$. We used a sensitive ELISA assay for measurement of $\mathrm{C} 3$ concentrations and calibrated it with known concentrations of purified human $\mathrm{C} 3$ as an internal 


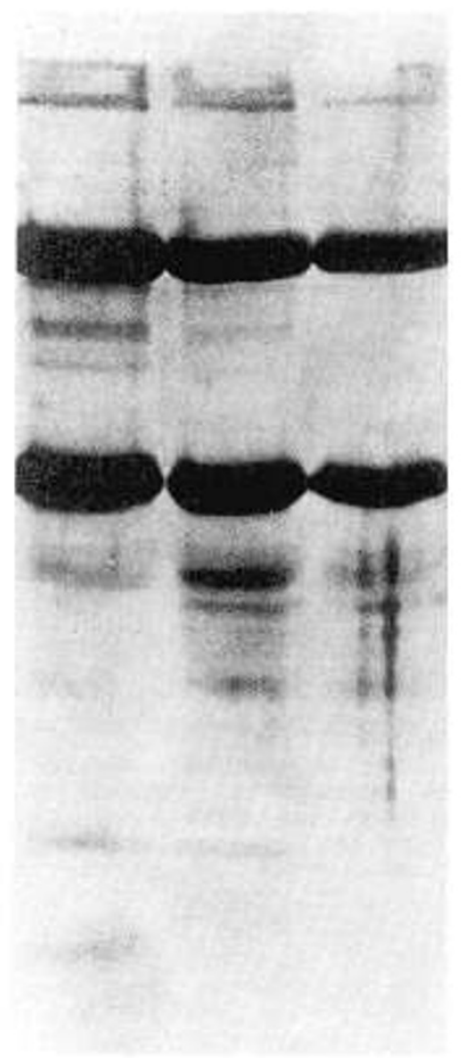

$205 \mathrm{Kd}$

$115 \mathrm{Kd}$

$75 \mathrm{Kd}$

Fig. 4. Structure of $\mathrm{C} 3$ isolated by affinity chromatography from three premature neonates and examined by $6 \%$ SDS-PAGE under reducing conditions. The two-chain structure of mature $\mathrm{C} 3$ is demonstrated with an $\alpha$-chain at $115 \mathrm{kD}$ and a $\beta$-chain at $75 \mathrm{kD}$. A single band at $205 \mathrm{kD}$ corresponding to the structure of pro-C 3 is also present.

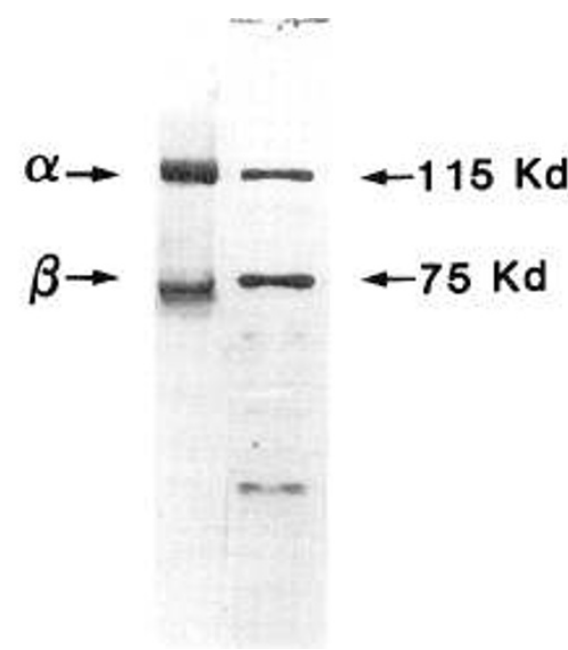

Fig. 5. Two-chain structure of $\mathrm{C} 3$ isolated by affinity chromatography from a premature neonate (right lane) and examined by Western blotting and immunodetection with goat anti-human C3. C3 standard shown in the left lane.

control, as well as with radial immunodiffusion. In comparison to full term infants, only extremely premature infants $(<30 \mathrm{wk}$ gestation) had significantly lower C3 levels (Fig. 1).

Previous studies of complement function in neonates have demonstrated impairments in both the classical and the alternative pathways (9-13). In several studies, decreases in complement-mediated opsonization or bacterial killing in neonatal serum have correlated with reduced serum levels of various complement components including factor B $(10,27), \mathrm{C} 3$ (28), $\mathrm{Clq}, \mathrm{C} 4$, and factor $\mathrm{H}(12)$. However, in many cases, defects in neonatal complement function have been reported despite relatively normal serum concentrations of $\mathrm{C} 3(10,12)$. These latter reports give rise to the hypothesis that the function of $\mathrm{C} 3$ may be aberrant in the neonate, even though the $\mathrm{C} 3$ concentration is essentially normal.

Our experiments test this hypothesis by assessing the function of the third component of complement in a system independent of other complement proteins. Furthermore, because nucleophilic amines bind stoichiometrically to reactive thiolester groups regardless of protein concentration, our assay is not influenced by differences in $\mathrm{C} 3$ concentration, or by the presence or absence of other complement proteins such as factors B, H, or I $(20,21)$ When we examined the reactivity of the $\mathrm{C} 3$ thiolester bond under these conditions we found a significant correlation with gestational age.

The critical level of functional C3 is unknown. Patients homozygous for $\mathrm{C} 3$ deficiency are markedly susceptible to severe infections with pyogenic organisms while their heterozygous parents, whose serum C3 concentrations are $50 \%$ of the norm, display no increased risk of infection $(29,30)$. Therefore, halfnormal serum concentrations of $\mathrm{C} 3$ are still protective, provided that each molecule is functionally active.

We defined functional $\mathrm{C} 3$ as the product of thiolester reactivity and C3 concentration. Nine of 11 premature infants and two of the 17 term newborns had concentrations of functional $\mathrm{C} 3$ which were less than $50 \%$ of the adult norm (Fig. 3). Although the results in prematures are not surprising, given their generally low serum concentrations, the results in term newborns may help to explain why a high proportion of early onset group B streptococcal disease arises in full-term infants despite adequate serum concentrations of complement proteins (31).

The aberrant structure of $\mathrm{C} 3$ in some newborns (Fig. 4) provides at best a partial explanation for the functional defects which we observed. Although local production of $\mathrm{C} 3$ by monocytes/macrophages (32), type II alveolar epithelial cells (33), and endothelial cells (34) is undoubtedly important at sites of inflammation which are sequestered from the bloodstream, $90 \%$ of total C3 is synthesized in the hepatocyte as a single-chain precursor molecule, pro-C3 (24). Posttranslational modification of pro-C3 includes proteolytic separation of $\alpha$ - and $\beta$-chains with formation of the disulfide bridge, deamination of a glutamine residue to the glutamyl of the intact thiolester, and glycosylation of the native two-chain structure (35-37).

The majority of posttranslational modification occurs intracellularly; however, the exact site of the reaction and nature of the responsible enzymes are unknown (37). Structural analysis of neonatal $\mathrm{C} 3$ revealed the two-chain structure in all neonates; four neonates had an additional band at $205 \mathrm{kD}$ which may represent unmodified pro-C3. In none of the four, however, was the amount of the $205-\mathrm{kD}$ band sufficient to account for the full degree of functional abnormality. An alternative explanation for this band is dimerization of $\alpha$-chains; however, this possibility is deemed unlikely because formation of disulfide bonds was blocked in our assay by alkylation with iodoacetamide. Moreover, the mol wt of $\alpha$-chain dimers $(230 \mathrm{kD})$ exceeds that which we observed $(205 \mathrm{kD})$.

It is unlikely that these observations are due to increased degradation of $\mathrm{C} 3$ because densitometric scanning quantified all bands other than those at 115 and $75 \mathrm{kD}$ as constituting $<10 \%$ of the total C3.

A possible explanation for decreased thiolester reactivity in neonatal C3 may be derived from the experiments of Iijima et al. (38). These investigators used rabbit liver mRNA to characterize an intermediate $\mathrm{C} 3$ translational product which failed to react with methylamine and was thus biochemically inactive; this defect was corrected by liver homogenate (38). It is well known that the activity of other fetal hepatic enzymes, such as UDP-glucuronyl transferase, is deficient in early gestation and 
matures with increasing gestational age (39). Other enzymatic or biochemical deficiencies in newborn liver may affect posttranslational modification of neonatal pro-C3.

In conclusion, these studies are the first to characterize and to quantitate a biochemical dysfunction of neonatal $\mathrm{C} 3$ which is independent of all other complement proteins. Because the functional integrity of the thiolester is required for opsonization of bacterial pathogens $(6,7)$, aberrant function of the thiolester bond in neonates may constitute a newly identified mechanism for the newborn's susceptibility to infection.

Acknowledgments. The authors thank Dr. Theodore Thompson, Chief, Division of Neonatology, for his support, Dr. Michael Georgieff for the provision of cord samples, and Dr. Ernest Gray for densitometric scanning.

\section{REFERENCES}

1. Siegel JD, McCracken GH Jr 1981 Sepsis neonatorum. N Engl J Med 304:642647

2. Cates KL, Rowe JC, Ballow M 1983 The premature infant as a compromised host. Curr Probl Pediatr 13:1-63

3. Wilson $\mathrm{CB} 1968$ Immunologic basis for increased susceptibility of the neonate to infection. J Pediatr 108:1-12

4. Edwards MS, Nicholson-Weller A, Baker CJ, Kasper DL 1980 The role of specific antibody in alternative complement pathway mediated opsonophagocytosis of type III, group B Streptococcus. J Exp Med 151:1275-1287

5. Von Dijk WC, Verbrugh HA, van der Tol ME, Peters R, Verhoef J 1979 Role of Escherichia coli $\mathrm{K}$ capsular antigens during complement activation, C3 fixation, and opsonization. Infect Immun 25:603-609

6. Hostetter MK, Krueger RA, Schmeling DJ 1984 The biochemistry of opsonization: central role of the reactive thiolester of the third component of complement. J Infect Dis 150:653-661

7. Hostetter MK, Krueger RA 1984 Role of the C3 thiolester in opsonization of type III group B Streptococci. Proceedings of the Third International Symposium on Infections in the Immunocompromised Host, Toronto, Ontario, Canada

8. Fireman P, Zuchowski DA, Taylor PM 1969 Development of human complement system. J Immunol 103:25-31

9. Ballow M, Fang F, Good RA, Day NK 1974 Developmental aspects of complement components in the newborn. Clin Exp Immunol 18:257-266

10. Johnston RB Jr, Altenburger KM, Atkinson AW, Curry RH 1979 Complement in the newborn infant. Pediatrics 64S:781-785

11. Adamkin D, Stitzel A, Urmson J. Farnett ML, Post E, Spitzer R 1978 Activity of the alternative pathway of complement in the newborn infant. J Pediatr 93:604-608

12. Edwards MS, Buffone GJ, Fuselier PA, Weeks JI, Baker CJ 1983 Deficient classical complement pathway activity in newborn sera. Pediatr Res 17:685688

13. Winkelstein JA, Kurlandsky LE, Swift AJ 1979 Defective activation of the third component of complement in the sera of newborn infants. Pediatr Res 13:1093-1096

14. Cairo MS, Worcester C, Rucker R, Bennetts GA, Amlie R, Perkin R, Anas N, Hicks D 1987 The role of circulating complement and polymorphonuclear leukocyte transfusion in the treatment and outcome of critically ill neonates with sepsis. J Pediatr 1 10:935-941

15. Tack BF, Janatova J, Thomas ML, Harrison RA, Hammer CH 1982 The third, fourth, and fifth components of human complement: isolation and biochemical properties. Methods Enzymol 80:64-101
16. Wilson MB, Nakane PK 1978 Immunofluorescence and Related Staining Techniques. Elsevier North-Holland Biomedical Press, Amsterdam, pp 215 224

17. Voller A, Bidwell D, Bartlett A 1980 Manual of Clinical Immunology. American Society for Microbiology, Washington D.C., pp 359-371

18. Gordon DL, Rice J, Finlay-Jones JJ, McDonald PJ, Hostetter MK 1988 Analysis of $\mathrm{C} 3$ deposition and degradation on bacterial surfaces after opsonization. J Infect Dis 157:697-704

19. Mancini G, Carbonara AO, Heremanns JF 1965 Immunochemical quantification of antigen by single radial immuno-diffusion. Immunochemistry $2: 235-254$

20. Tack BF, Harrison RA, Janatova J, Thomas ML, Prahl JW 1980 Evidence for presence of an internal thiolester bond in third component of human complement. Proc Natl Acad Sci USA 77:5764-5768

21. Hostetter MK, Krueger RA, Nath KA, Hostetter TH 1984 Nucleophilic attack on complement component $C 3$ in chronic renal failure. Fed Proc 43:1617

22. Laemmli UK 1970 Cleavage of structural proteins during assembly of the head of bacteriophage T4. Nature 227:680-685

23. Towbin H, Staehelin T, Gordon J 1979 Electrophoretic transfer of proteins from polyacrylamide gels to nitrocellulose sheets: procedure and some applications. Proc Natl Acad Sci USA 76:4350-4354

24. Goldberger G, Thomas ML, Tack BF, Williams J, Colten HR, Abraham GN $1981 \mathrm{NH}_{2}$-terminal structure and cleavage of guinea-pig pro-C3, the precursor of the third component of complement. J Biol Chem 256:12616-12619

25. Thomas ML, Janatova J, Gray WR, Tack BF 1982 Third component of human complement: localization of the internal thiolester bond. Proc Natl Acad Sci USA 79:1054-1058

26. Hostetter MK, Thomas ML, Rosen FS, Tack BF 1982 Binding of C3b proceeds by a transesterification reaction at the thiolester site. Nature 298:72-75

27. Stossel TP, Alper CA, Rosen FS 1973 Opsonic activity in the newborn: role of properdin. Pediatrics 52:134-137

28. McCracken GH Jr., Eichenwald HF 1971 Leukocyte function and development of opsonic and complement activity in the neonate. Am J Dis Child 121:120126

29. Alper CA, Colten HR, Rosen FS, Rabson AR, Macnab GM, Gear JSS 1972 Homozygous deficiency of $\mathrm{C} 3$ in a patient with repeated infections. Lancet 2:1179-1181

30. Borzy MS, Gewruz A, Wolff, L, Houghton D, Lovrien E 1988 Inherited C3 deficiency with recurrent infections and glomerulonephritis. Am J Dis Child 142:79-83

31. Baker CA 1986 Group B streptococcal infection in newborns: prevention at last? N Engl J Med 314:1702-1704

32. Cole FS, Matthews WJ, Rossing TH, Gash DJ, Lichtenberg NA, Pennington JE 1983 Complement biosynthesis by human bronchoalveolar macrophages. Clin Immunol Immunopathol 27:153-159

33. Strunk RC, Eidlen DM, Mason RJ 1988 Pulmonary alveolar type II epithelial cells synthesize and secrete proteins of the classical and alternative complement pathways. J Clin Invest 81:1419-1426

34. Ueki A, Sai T, Oka H, Tabata M, Hosokawa K, Mochizuki Y 1987 Biosynthesis and secretion of the third component of complement by human endothelial cells in vitro. Immunology 61:11-14

35. Domdey H, Wiebauer K, Kazmaier M, Mulller V, Odink K, Fey G 1982 Characterization of the mRNA and cloned CDNA specifying the third component of mouse complement. Proc Natl Acad Sci USA 79:7619-7623

36. Tack BF, Morris SC, Prahl JW 1979 Third component of human complement structural analysis of the polypeptide chains of $\mathrm{C} 3$ and $\mathrm{C} 3 \mathrm{~b}$. Biochemistry 18:1497-1503

37. Bednarczyk JL, Capra JD 1988 Post-translational processing of the murine third component of complement. Scand J Immunol 27:83-95

38. Iijima M, Tobe T, Sakamoto T, Tomita M 1984 Biosynthesis of the internal thiolester bond of the third component of complement. J Biochem 96:15391546

39. Kawade N, Onishi S 1981 The prenatal and postnatal development of UDPglucuronyl transferase activity toward bilirubin and the effect of premature birth on this activity in the human liver. Biochem $J$ 196:257-260 